Article

\title{
Ethylene Oligomerization over Nickel Supported Silica-Alumina Catalysts with High Selectivity for $\mathrm{C}_{10+}$ Products
}

\author{
Lei Chen ${ }^{1,2}$, Guangci Li ${ }^{1, *}$, Zhong Wang ${ }^{1}\left(\mathbb{D}\right.$, Shuangju Li ${ }^{1,2}$, Mingjie Zhang ${ }^{1}$ and Xuebing Li ${ }^{1, *}$ \\ 1 Key Laboratory of Biofuels, Qingdao Institute of Bioenergy and Bioprocess Technology, Chinese Academy of \\ Science, No.189 Songling Road, Laoshan District, Qingdao 266101, China; chenlei@qibebt.ac.cn (L.C.); \\ wangzhong@qibebt.ac.cn (Z.W.); lisj@qibebt.ac.cn (S.L.); zhang_mj@qibebt.ac.cn (M.Z.) \\ 2 University of Chinese Academy of Science, No.19A Yuquan Road, Beijing 100049, China \\ * Correspondence: ligc@qibebt.ac.cn (G.L.); lixb@qibebt.ac.cn (X.L.); Tel./Fax: +86-532-80662757
}

Received: 13 January 2020; Accepted: 31 January 2020; Published: 3 February 2020

check for updates

\begin{abstract}
The nickel (II) loading silica-alumina under various treatments in terms of aging temperature, $\mathrm{Si} / \mathrm{Al}$ ratio and activation temperature were investigated by $\mathrm{XRD}, \mathrm{N}_{2}$ adsorption-desorption, TEM, $\mathrm{UV}$-Vis, $\mathrm{NH}_{3}$-TPD and XRF and then applied to catalyze the ethylene oligomerization. High aging temperature, low $\mathrm{Si} / \mathrm{Al}$ ratio and high activation temperature were beneficial to high selectivity for $\mathrm{C}_{10+}$ products because of a reasonable match between $\mathrm{Ni}$ active sites and acid sites, high $\mathrm{Ni}$ loading content and less octahedral coordination $\mathrm{Ni}^{2+}$ species, respectively. $\mathrm{Ni}$ loading content was more important than the number of acid sites for high yield of $\mathrm{C}_{10+}$ products, and less octahedral coordination $\mathrm{Ni}^{2+}$ species favored less by-products produced at high reaction temperature. In addition, other experimental conditions, such as reaction temperature, weight hourly space velocity (WHSV) and nickel precursor were discussed in the paper.
\end{abstract}

Keywords: ethylene oligomerization; $\mathrm{Ni}-\mathrm{SiO}_{2}-\mathrm{Al}_{2} \mathrm{O}_{3} ; \mathrm{Si} / \mathrm{Al}$ ratio; synthesis aging temperature; octahedral coordination $\mathrm{Ni}^{2+}$

\section{Introduction}

The oligomerization of light olefins is an important route for the production of linear and branched higher olefins, which can be used in the manufacture of detergents, petrochemicals, oil additives, high-octane ecological gasoline, etc. [1,2]. Ethylene, with huge production worldwide, is the raw material for a wide range of chemical products and intermediates. Industrial reactions of ethylene include in order of scale polymerization, oxidation, halogenation, alkylation, hydration, oligomerization and hydroformylation [3-6]. Ethylene oligomerization is of considerable academic and industrial interest because it is one of the major processes for production of linear and branched higher olefins, which are components of plastics $\left(C_{4}-C_{6}\right.$ in copolymerization), plasticizers $\left(C_{6}-C_{10}\right.$ through hydroformylation), lubricants $\left(\mathrm{C}_{10}-\mathrm{C}_{12}\right.$ through oligomerization) and surfactants $\left(\mathrm{C}_{12}-\mathrm{C}_{16}\right.$ through arylation/sulphonation) or starting materials for other important chemicals, such as propylene, alcohols, amines and acids [1,7-13]. Among those higher olefins products, $C_{10+}$ is very desirable for jet fuel application [14-16].

The $\mathrm{C}_{10+}$ olefins produced from ethylene can be fulfilled by using homogeneous [17-20] and heterogeneous catalysts [21-23] where heterogeneous catalysts have been extensively explored because of easily separation from the product and better reusability. Among those heterogeneous catalyst systems, Ni-base catalysts have attracted much attention because of high activity and selectivity towards the $\mathrm{C}_{10+}$ olefins [1,24-30]. The oligomerization on Ni-based catalysts coupled with co-oligomerization reactions involving the primary olefins over an acid catalyst is favorable for obtaining the olefins with 
$\mathrm{C}_{10+}$ chain. In order to illustrate the role of nickel sites and acid sites in this reaction, the total reaction pathways were proposed, as shown in Scheme 1 [6].

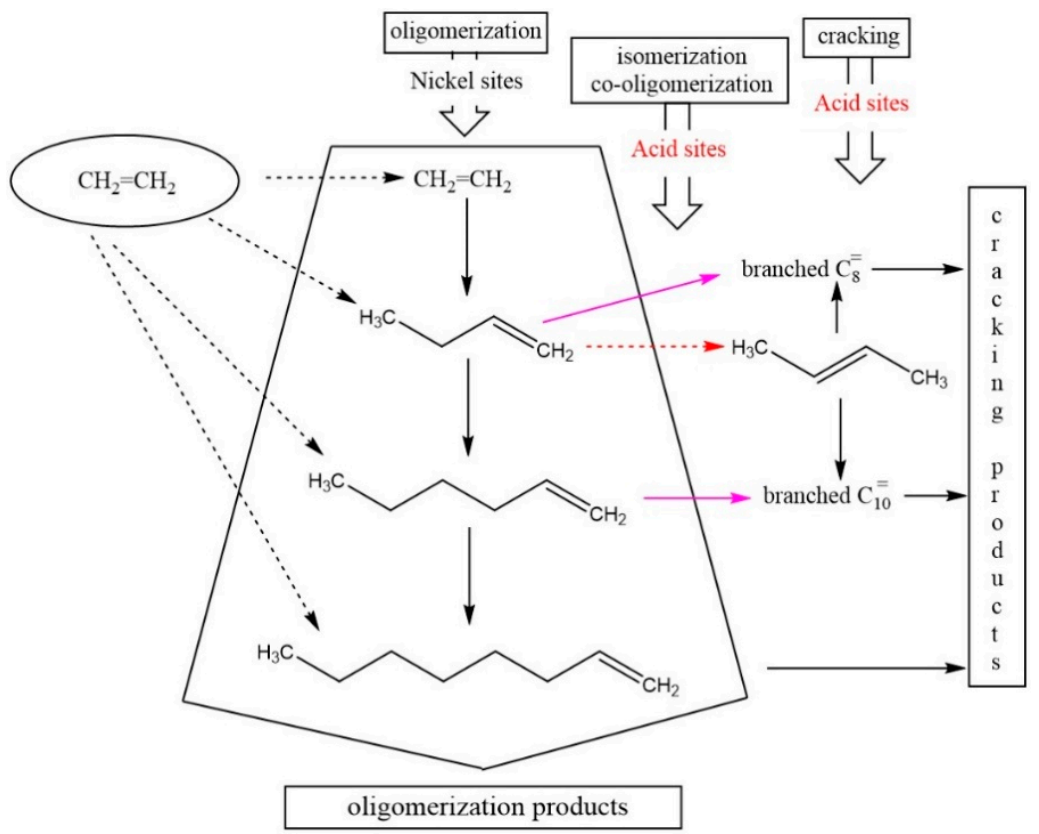

Scheme 1. Reaction pathway in the ethylene oligomerization process ${ }^{6}$.

The first reaction is based on the coordination chemistry on nickel sites. They act as active sites for both the initial oligomerization of ethylene and further oligomerization reactions involving butene-ethylene coupling, leading to linear olefins of medium-chain length. The second one is based on the acid catalysis. Over acid sites, the $\mathrm{C}_{4}$ and $\mathrm{C}_{6}$ olefins can be consumed through co-oligomerization reactions (mechanism involving carbenium ions), leading to the formation of octenes or higher branched olefins, respectively. These reactions are essentially favored by a stronger acidity or/and a higher acid sites concentration and higher reaction temperatures. The same factors are responsible for the isomerization of the initial product (1-butene, 1-hexene, etc.). The $C_{4}-C_{10}$ oligomers can be involved in further acid catalyzed reactions, leading to the formation of heavy hydrocarbons which are responsible for pore blocking and catalyst deactivation. The third type of reaction, occurring under severe conditions and involving the acid sites, consists in the cracking of the primary and secondary oligomers and $\mathrm{H}$ transfer.

In most previous studies, the active Ni species are often loaded on the different supports, such as silica ${ }^{17}$, silica-alumina [6,24] and zeolites [31-34], to improve the dispersion of Ni species. Meanwhile, the activity and selectivity towards the $\mathrm{C}_{10+}$ olefins are also affected with the change in the acid sites and the porosity of the supports. For example, $\mathrm{Ng}$ et al. [33] investigated the effect of $\mathrm{NaY}$ zeolites supports by the acid and base treatment and the calcination temperature, and found that Ni species and acid sites were necessary for the oligomerization of ethylene. Lallem and et al. [28] reported that the Ni-exchanged MCM-36 zeolite exhibited higher activity and stability than the Ni-exchanged MCM-22 zeolite because the mesoporous nature of the MCM-36 zeolite facilitates the diffusion of larger oligomers formed during the reaction.

Apart from the zeolites and mesoporous silica, silica-alumina support was the earlier candidate because of their merits of easy synthesis and cheapness. Compared with zeolite materials, silica-alumina support has the moderate strength acid sites that benefit to lower the extent of over-polymerization of ethylene, thus inhibiting the coke formation. Moreover, silica-alumina support also has the interparticle mesopores which facilitate the larger oligomers diffusion. Heveling et al. [34] employed this catalytic system to obtain products in the $C_{4}-C_{20}$ range from ethylene and found these types of catalysts were extremely stable, showing no detectable drop in conversion after 108 days. Previous 
studies on Ni-loading silica-alumina mainly investigated the effect of reaction conditions [34] (reaction temperature and gas pressure) and the reactor type (fixed-bed reactor [34] and the slurry reactor [24]). In this work, we focused on the effect of the modification of the silica-alumina support in terms of aging temperature, the ratio of $\mathrm{Si} / \mathrm{Al}$ and activation temperature and the $\mathrm{C}_{10+}$ yield was employed to evaluate these effects. In addition, we investigated the effects of other experimental conditions on the experimental results, such as reaction temperature, weight hourly space velocity (WHSV) and nickel precursor.

\section{Results and Discussion}

\subsection{The Physicochemical Properties of Ni/Si-Al Catalysts}

Figure 1 shows the $\mathrm{XRD}$ patterns of as-obtained $\mathrm{Si}-\mathrm{Al}$ support and $\mathrm{Ni} / \mathrm{Si}-\mathrm{Al}$ catalyst with different $\mathrm{Si}$ Al ratios treated at different aging temperatures. For all samples, including Si-Al support and $\mathrm{Ni} / \mathrm{Si}-\mathrm{Al}$ catalysts, there was only a broad peak locating at around $22.5^{\circ}$ and no sharp peaks attributed to $\mathrm{Al}_{2} \mathrm{O}_{3}$ were observed, indicating its amorphous structure and that they were composed of small particles with poor crystallinity. Accordingly, the ratio of $\mathrm{Si} / \mathrm{Al}$ and aging temperature cannot influence the crystalline structure of $\mathrm{Si}-\mathrm{Al}$ support and $\mathrm{Ni} / \mathrm{Si}-\mathrm{Al}$ catalyst under present synthesis condition.

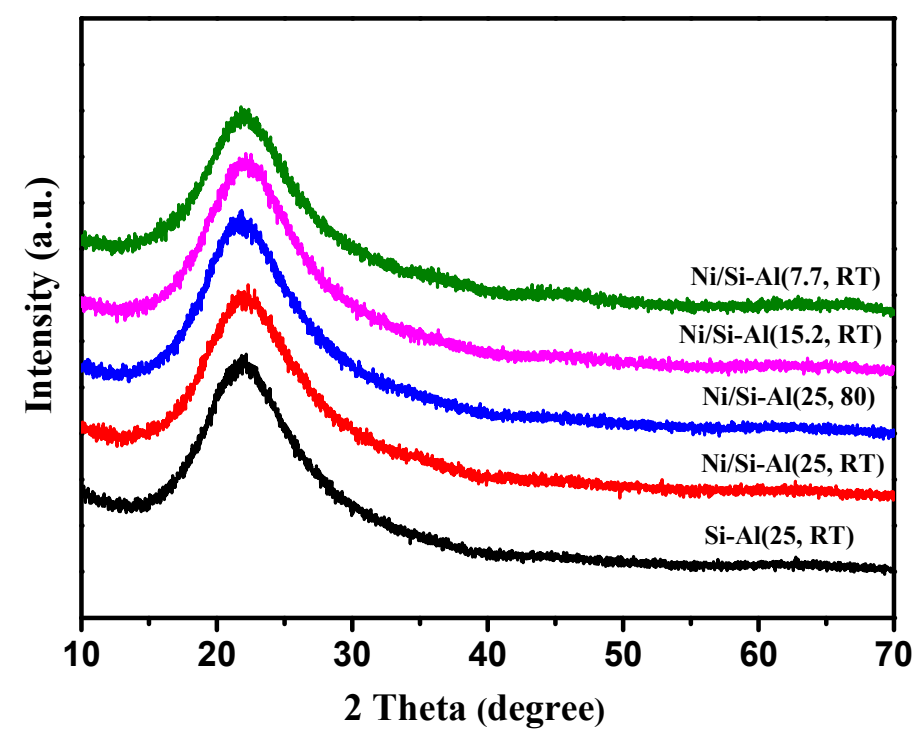

Figure 1. The XRD patterns of prepared catalysts at different conditions.

After loading Ni onto Si-Al support, there was no obvious peaks attributed to $\mathrm{NiO}$ in XRD patterns for all Ni/Si-Al catalysts, but XRF texts (as shown in Table 1) verified that Ni species does exist on the support surface. The diffraction peaks for Ni species were not found in XRD patterns, resulted from the lower amount of $\mathrm{Ni}$ loading by ion-exchange method and the well dispersity of $\mathrm{Ni}$ on the support surface, which is beneficial to the catalytic performance.

Table 1. The catalysts prepared by $\mathrm{Ni}\left(\mathrm{NO}_{3}\right)_{2}$-sodium silicate- $\mathrm{NaAlO}_{2}$ and their physical properties.

\begin{tabular}{|c|c|c|c|c|}
\hline Catalysts & $\mathrm{Ni}(\%)^{a}$ & Surface Area $\left(\mathrm{m}^{2} / \mathrm{g}\right)^{\mathrm{b}}$ & $V_{\text {meso }}\left(\mathrm{m}^{3} / \mathrm{g}\right)^{b}$ & Acid Amount (mmol/g) ${ }^{c}$ \\
\hline $\mathrm{Ni} / \mathrm{Si}-\mathrm{Al}(25, \mathrm{RT})$ & 1.36 & 180 & 0.71 & 0.5 \\
\hline Ni/Si-Al $(25,80)$ & 1.34 & 219 & 0.79 & 0.49 \\
\hline Ni/Si-Al $(15.2, \mathrm{RT})$ & 1.45 & 107 & 0.41 & 0.41 \\
\hline $\mathrm{Ni} / \mathrm{Si}-\mathrm{Al}(7.7, \mathrm{RT})$ & 1.94 & 97 & 0.40 & 0.37 \\
\hline
\end{tabular}

a determined by XRF. ${ }^{b}$ determined by $\mathrm{N}_{2}$ adsorption-desorption test (Table S1). ${ }^{\mathrm{c}}$ determined by $\mathrm{NH}_{3}$-TPD (Figure S1 and Table S2). 
Figure 2 shows the morphology of the Ni/Si-Al catalysts with different $\mathrm{Si} / \mathrm{Al}$ ratio or aging temperature. The resultant sample shows that $\mathrm{Ni} / \mathrm{Si}-\mathrm{Al}$ catalysts at different aging temperatures had a uniform spherical morphology with the particle size in the range of $20-30 \mathrm{~nm}$, while with increasing the aging temperature, there was no obvious change in the morphology and particle size (Figure 2A and B, $\mathrm{Ni} / \mathrm{Si}-\mathrm{Al}(25, \mathrm{RT})$ vs. Ni/Si-Al $(25,80))$. However, when the ratio of Si/Al was decreased from 25 to 12.5 , the single spherical particles disappeared and adjacent particles began to grow and combine into worm-like particles with the size of $50 \mathrm{~nm}$ and more (Figure 2A,C, Ni/Si-Al (25, RT) vs. Ni/Si-Al (12.5, $\mathrm{RT})$. As the ratio of $\mathrm{Si} / \mathrm{Al}$ was further decreased, the worm-like particles grew into larger aggregates (Figure 2D, Ni/Si-Al (7.7, RT)).

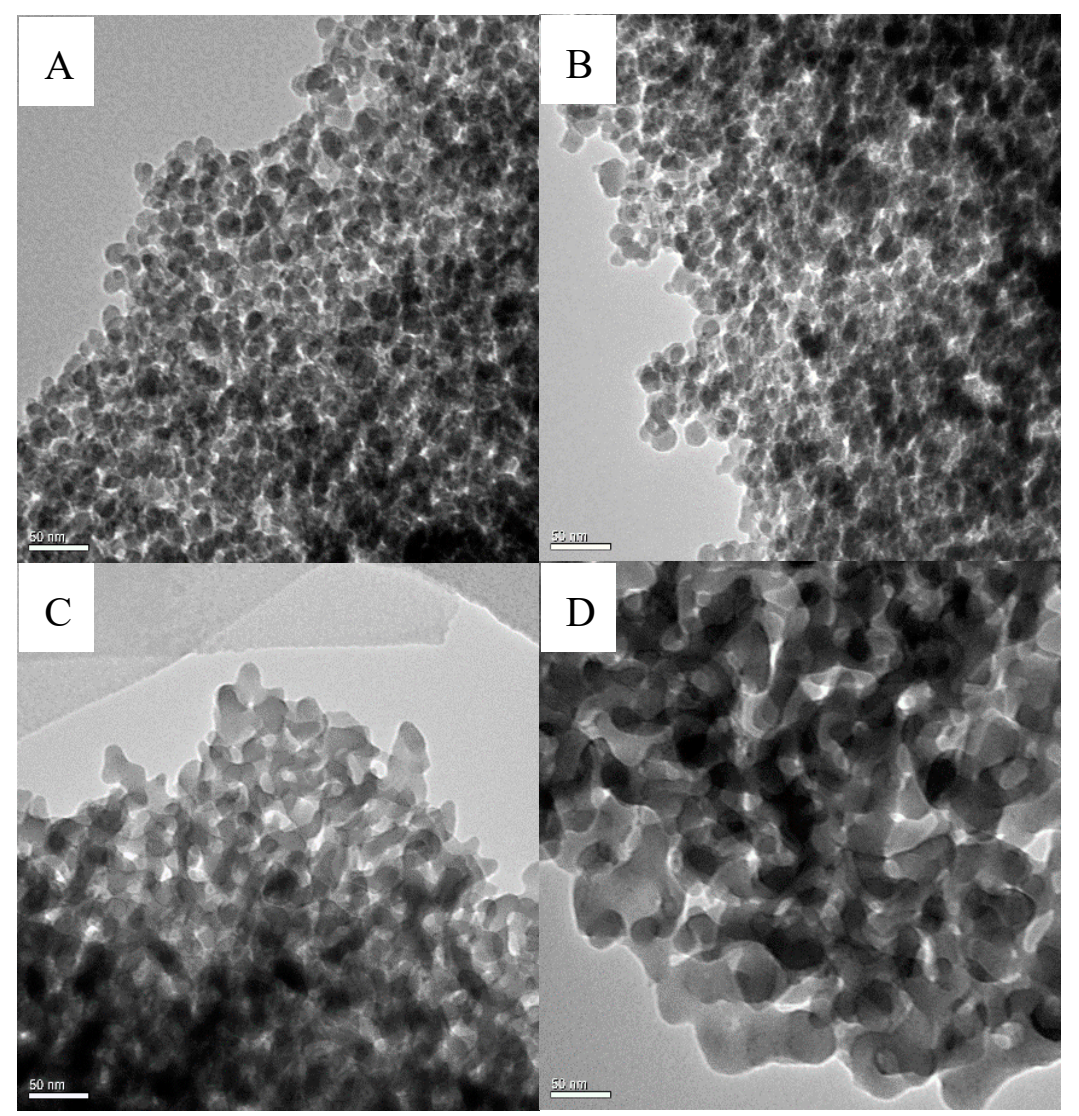

Figure 2. TEM images of prepared catalysts: (A) Ni/Si-Al (25, RT); (B) Ni/Si-Al $(25,80)$; (C) Ni/Si-Al $(15.2, \mathrm{RT}) ;($ D) Ni/Si-Al $(7.7, \mathrm{RT})$.

The change in morphology would result in some differences in textural properties of Ni/Si-Al catalysts. The increase in particle size inevitably resulted in the decrease of the surface area, as shown in Figure 3 and Table 1. Nitrogen sorption isotherms for the Ni/Si-Al (x,y) are shown in Figure 3. According to the International Union of Pure and Applied Chemistry (IUPAC) classification, all isotherms are of type IV [35]. Their sharp capillary condensation steps are indicative of a narrow mesopore size distribution. The highly parallel adsorption and desorption branches in the hysteresis loop indicate that the sample possesses uniform mesopores. Despite the similar shape of isotherms, the adsorption amount of the three samples is different, which means some differences in their textural properties. Based on the results calculated by Brunauer-Emmett-Teller (BET) and Barrett-Joyner-Halenda (BJH) methods, as the ratio of $\mathrm{Si} / \mathrm{Al}$ decreased, the specific surface area decreased in order $\left(180>107>97 \mathrm{~m}^{2} / \mathrm{g}\right)$ as well as the pore volume $\left(0.71>0.41>0.40 \mathrm{~cm}^{3} / \mathrm{g}\right)$ (Table 1$)$. These changes would affect the dispersion of $\mathrm{Ni}$ and corresponding catalytic activity. Compared with $\mathrm{Ni} / \mathrm{Si}-\mathrm{Al}(25, \mathrm{RT}), \mathrm{Ni} / \mathrm{Si}-\mathrm{Al}(25,80)$ catalyst had higher surface area and Vmeso, indicating that treating the catalysts at higher temperature was benefited to an increase in the surface area and Vmeso. 


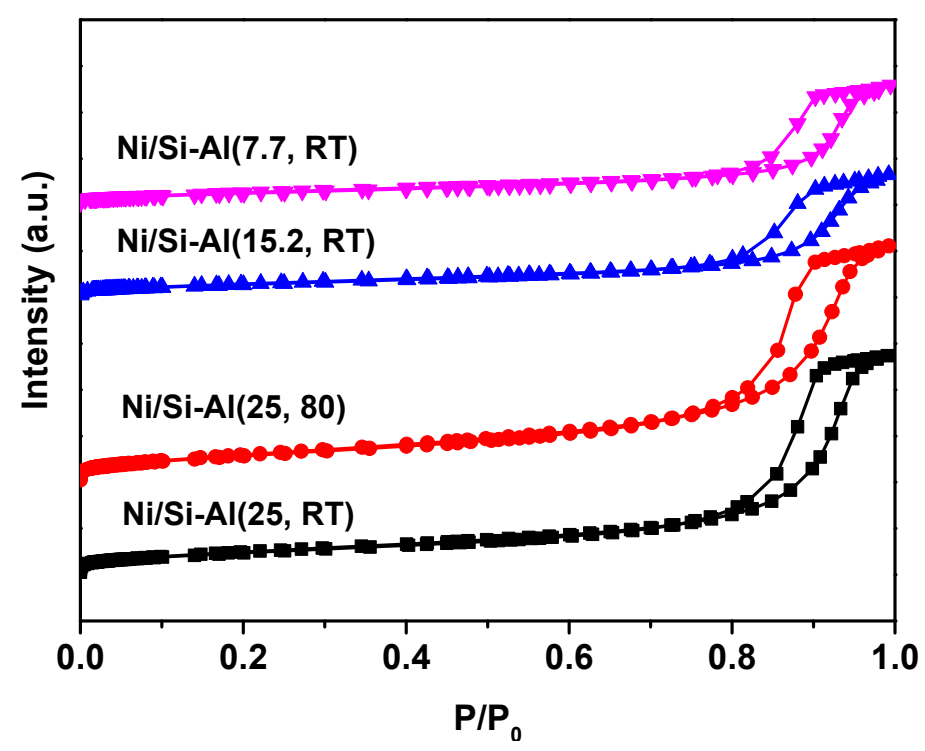

Figure 3. $\mathrm{N}_{2}$ adsorption-desorption isotherms at $77 \mathrm{~K}$ determined on $\mathrm{Ni} / \mathrm{Si}-\mathrm{Al}(\mathrm{x}, \mathrm{y})$.

For the acidity property, the total acid amount remained constant after treating at different temperature $(0.5 \mathrm{mmol} / \mathrm{g}$ in Ni/Si-Al $(25, \mathrm{RT})$ vs. $0.49 \mathrm{mmol} / \mathrm{g}$ in Ni/Si-Al $(25,80))$, but decreased with the Si:Al ratio (Table 1, Ni/Si-Al $(25, \mathrm{RT})>\mathrm{Ni} / \mathrm{Si}-\mathrm{Al}(15.2, \mathrm{RT})>\mathrm{Ni} / \mathrm{Si}-\mathrm{Al}(7.7, \mathrm{RT}))$. It has been well documented that the acid sites on the surface of silica-alumina were mostly from the alumina addition [6,36-38]. This unexpected decreased acid amount was presumably attributed to the increase of Ni loading content, which may occupy the acid sites (Table 1). In each sample, there was no obvious change in the acid strength, indicating that the $\mathrm{Si} / \mathrm{Al}$ ratio had no effect on the distribution of acid strength (Table S1). Furthermore, since $\mathrm{Na}^{+}$ions are exchanged with $\mathrm{Ni}^{2+}$ ions, the loading content of $\mathrm{Ni}$ species is proportional to the content of $\mathrm{Na}^{+}$ions (Table 1, Ni/Si-Al $(7.7, \mathrm{RT})>\mathrm{Ni} / \mathrm{Si}-\mathrm{Al}(15.2, \mathrm{RT})>$ $\mathrm{Ni} / \mathrm{Si}-\mathrm{Al}(25, \mathrm{RT}))$.

\subsection{Ethylene Oligomerization Reaction Tests}

As mentioned above, the catalyst property and reaction condition will affect the properties of ethylene oligomers remarkably. Thus, the effects of several factors on ethylene oligomerization were investigated respectively, including reaction temperature, WHSV, Ni precursor, aging temperature, the ratio of $\mathrm{Si} / \mathrm{Al}$ and pretreatment temperature of catalyst.

\subsubsection{The Effect of Reaction Temperature}

In order to investigate the effect of reaction temperature on the ethylene oligomerization, a series of experiments at different temperatures were carried out. The gas phase product at all reaction temperatures, the content of butene is above $98 \%$, considering the composition of the liquid phase product together, it can be concluded that the conversion of ethylene is above $98 \%$. As shown in Figure 4 , it can be seen that the olefins with low carbon number $\left(C_{6}\right.$ and $\left.C_{8}\right)$ are predominant in the liquid product when the reaction proceeded below $200^{\circ} \mathrm{C}$.

\subsubsection{The Effect of Weight Hourly Space Velocity (WHSV)}

Space velocity is one of important factors for heterogeneous catalysis reaction, which represents the time of reactant contact with catalyst. For investigating the effect, the reaction was conducted with WHSV in the range from 2.0 to $3.72 \mathrm{~h}^{-1}$, and the conversion of ethylene is above $95 \%$ with different yield of liquid, the result is shown in Figure 5. It was found that the liquid yield is dependent on WHSV. When WHSV was controlled to be $2.0 \mathrm{~h}^{-1}$, the liquid yield was about $40 \%$. Although reducing WHSV could prolong the time of ethylene contact with catalyst and improve oligomerization reaction, 
long-time contact would lead to excessive oligomerization of olefins into carbon, inducing low liquid yield. When WHSV was increased more than $3.0 \mathrm{~h}^{-1}$, the liquid yield further decreased. This may be due to the time of contact of ethylene with catalyst being too short, which results in that the as-obtained short-chain olefins with detached from catalyst before further reaction. When WHSV was $2.8 \mathrm{~h}^{-1}$, the highest liquid yield was obtained.

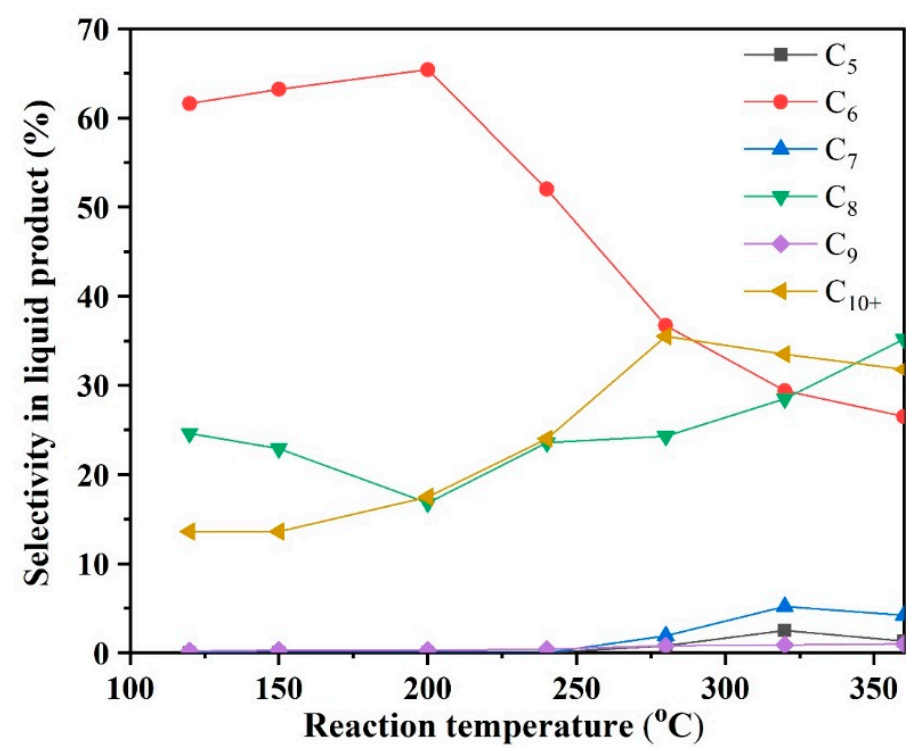

Figure 4. Effect of reaction temperature on the selectivity in the liquid product. Reaction conditions: $\mathrm{Si} / \mathrm{Al}$ ratio: 25 ; pressure: $3.5 \mathrm{MPa}$; WHSV: $2.0 \mathrm{~h}^{-1}$; Ni precursor: $\mathrm{Ni}\left(\mathrm{NO}_{3}\right)_{2}$; aging temperature: room temperature; pretreatment temperature: $300^{\circ} \mathrm{C}$. As the reaction temperature was increased, the contents of $\mathrm{C}_{6}$ and $\mathrm{C}_{8}$ decreased gradually, accordingly, the contents of $\mathrm{C}_{10+}$ increased obviously. When the temperature was beyond $300{ }^{\circ} \mathrm{C}$, the olefins with odd carbon number $\left(\mathrm{C}_{5}, \mathrm{C}_{7}\right.$ and $\left.\mathrm{C}_{9}\right)$ appeared, indicating that cracking reaction took place. Thus, high temperature is favorable for the formation of $\mathrm{C}_{10+}$ olefins, but too high temperature will affect the liquid yield because of cracking reaction.

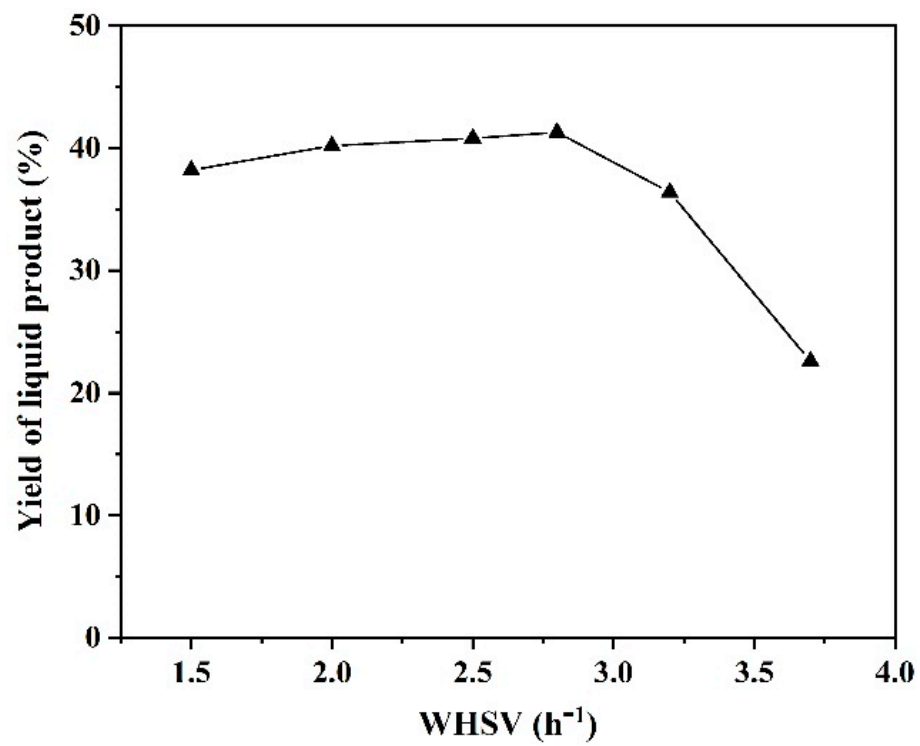

Figure 5. Effect of WHSV on the yield of liquid product. Reaction conditions: reaction temperature: $120^{\circ} \mathrm{C}$; $\mathrm{Si} / \mathrm{Al}$ ratio: 25 ; pressure: $3.5 \mathrm{MPa}$; $\mathrm{Ni}$ precursor: $\mathrm{Ni}\left(\mathrm{NO}_{3}\right)_{2}$; aging temperature: room temperature; pretreatment temperature: $300^{\circ} \mathrm{C}$. 


\subsubsection{The Effect of the Ni Precursors}

To understand how the Ni precursor affects the Ni/Si-Al activity, two kinds of catalysts were prepared by using $\mathrm{Ni}\left(\mathrm{NO}_{3}\right)_{2}$ and $\mathrm{NiCl}_{2}$ as the $\mathrm{Ni}$ precursor, respectively. As seen from Figure 6, the activity of $\mathrm{Ni} / \mathrm{Si}-\mathrm{Al}$ derived from $\mathrm{Ni}\left(\mathrm{NO}_{3}\right)_{2}$ is better than that of $\mathrm{Ni} / \mathrm{Si}-\mathrm{Al}$ derived from $\mathrm{NiCl}_{2}$ at low reaction temperature. When the temperature exceeded $280{ }^{\circ} \mathrm{C}, \mathrm{Ni} / \mathrm{Si}$ - $\mathrm{Al}$ derived from $\mathrm{NiCl}_{2}$ exhibits higher activity. This result is relative to the Ni precursor, especially anions. The detailed effect mechanism needs further investigation.

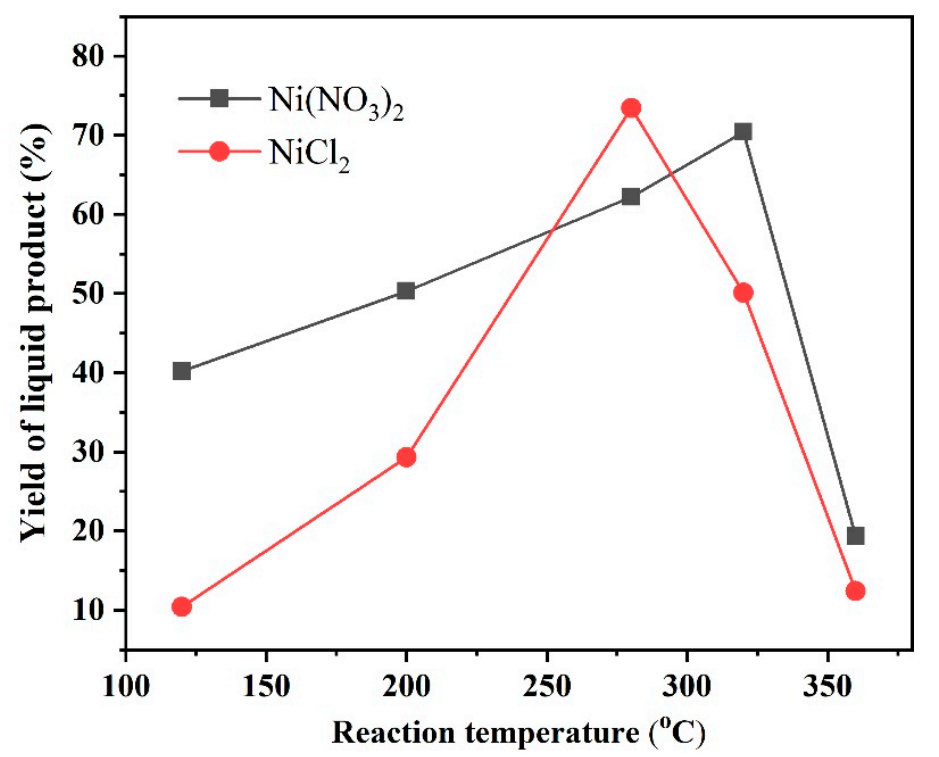

Figure 6. Effect of Ni precursor on the yield of liquid product. Reaction conditions: Si/Al ratio: 25; pressure: $3.5 \mathrm{MPa}$; WHSV: $2.0 \mathrm{~h}^{-1}$; aging temperature: room temperature; pretreatment temperature: $300^{\circ} \mathrm{C}$.

\subsubsection{The Effect of Aging Temperature}

Figure 7 showed the result of as-obtained catalysts catalyzed ethylene oligomerization, where the yield of $\mathrm{C}_{10+}$ products was used as an indicator for evaluating their performance. With increasing the reaction temperature, the yield of $\mathrm{C}_{10+}$ products obtained from both Ni/Si-Al $(25, \mathrm{RT})$ and Ni/Si-Al $(25,80)$ first increased (below $280^{\circ} \mathrm{C}$ ) and then decreased (above $280^{\circ} \mathrm{C}$ ). This was because increasing temperature favored accelerating the rate of ethylene oligomerization, but too high a temperature led to undesirable side reactions, resulting in low selectivity for $\mathrm{C}_{10+}$ products. Compared with $\mathrm{Ni} / \mathrm{Si}-\mathrm{Al}$ $(25, \mathrm{RT}), \mathrm{Ni} / \mathrm{Si}-\mathrm{Al}(25,80)$ catalyst could deliver higher $\mathrm{C}_{10+}$ products at all reaction temperatures used, indicating that aging the catalysts at high temperature was beneficial to its catalytic performance.

For catalysts with little difference in acid property and similar Ni loading content (As shown in Table 1), the reaction results were different. The reason is that as the aging temperature increases, the degree of condensation of the $\mathrm{Si}-\mathrm{Al}$ support increases, that is, the dispersion of $\mathrm{Si}-\mathrm{O}-\mathrm{Al}$ is more uniform. Considering the mutual combination of $\mathrm{Na}$ and $\mathrm{Al}$ in the support, the dispersibility and the spatial order of $\mathrm{Na}$ is improved, and the loading of $\mathrm{Ni}$ is obtained by the exchange of $\mathrm{Ni}$ and $\mathrm{Na}$, so the spatial order of $\mathrm{Ni}$ is improved $[6,23,25]$. One result of uniform dispersion of nickel is a reasonable match between $\mathrm{Ni}$ active sites and acid sites. The combination of a reasonable match between $\mathrm{Ni}$ active and acid sites can be seen as a "more efficient active site" for ethylene oligomerization, consistent with previous reports [28]. Figure 8 intuitively showed the benefit of high dispersity of Ni sites. In an oligomerization catalytic cycle, there will be (I) desorption of primary oligomers and (II) re-adsorption at acid sites for secondary oligomerization events, "more efficient active site" include Ni active sites and acid sites on the catalysts surface, can facilitate the transfer of reaction intermediates between two 
active sites, so that the intermediate products continue to react to give longer carbon chain products. That is, the percentage of the $\mathrm{C}_{10+}$ products increased the oligomerization products.

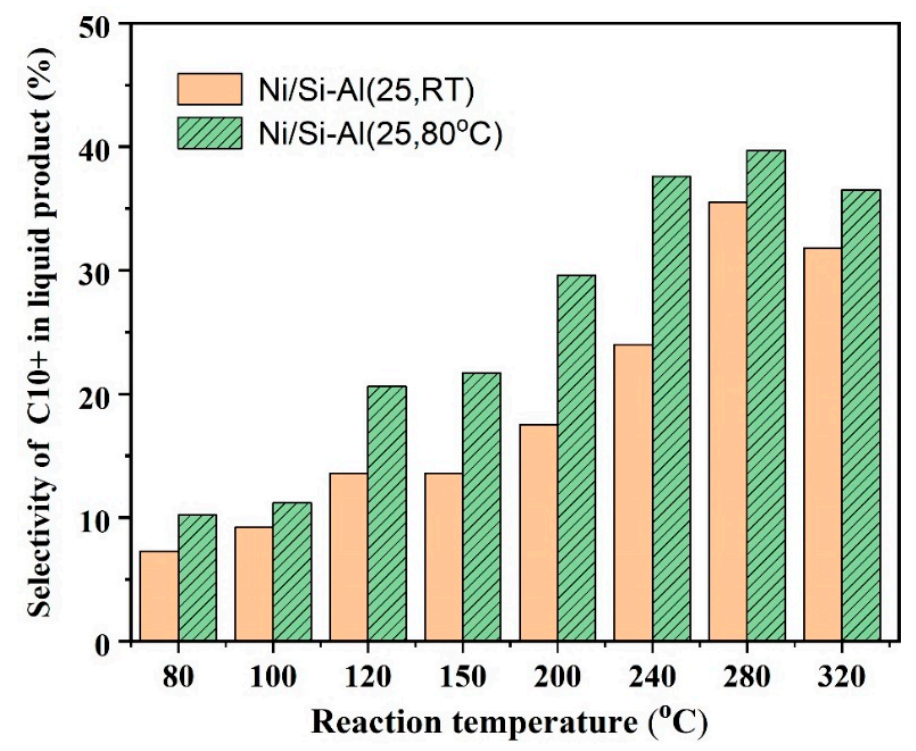

Figure 7. $\mathrm{C}_{10+}$ product of ethylene oligomerization catalyzed by Ni/Si-Al $(25, \mathrm{RT})$ and $\mathrm{Ni} / \mathrm{Si}-\mathrm{Al}(25$, 80 ) at different reaction temperatures. Reaction conditions: pressure: $3.5 \mathrm{MPa}$; WHSV: $2.0 \mathrm{~h}^{-1}$; Ni precursor: $\mathrm{Ni}\left(\mathrm{NO}_{3}\right)_{2}$; aging temperature: room temperature; pretreatment temperature: $300{ }^{\circ} \mathrm{C}$.

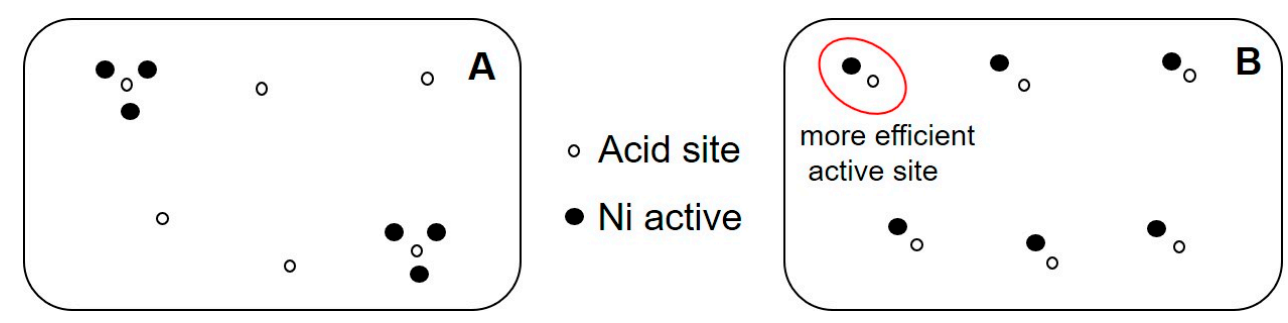

Figure 8. Match scheme of nickel and acid sites of (A) low nickel dispersed degree and (B) high nickel dispersed degree.

\subsubsection{The Effect of the Ratio of Si/Al}

As discussed above, changing the ratio of $\mathrm{Si} / \mathrm{Al}$ of these catalysts could affect its properties involving morphology, structure and textural properties. It is believed that these properties are related to the catalytic performance of the $\mathrm{Ni} / \mathrm{Si}-\mathrm{Al}$ catalyst.

The catalytic performances of these catalysts with different $\mathrm{Si} / \mathrm{Al}$ ratios are shown in Figure 9. At the same reaction temperature, decreased $\mathrm{Si} / \mathrm{Al}$ ratio is favorable for the formation of $\mathrm{C}_{10+}$ olefins when the reaction temperature is below $240{ }^{\circ} \mathrm{C}$. With increasing the reaction temperature, the yield of $\mathrm{C}_{10+}$ products from Ni/Si-Al $(25, \mathrm{RT})$ and Ni/Si-Al $(15.2, \mathrm{RT})$ continually increased, while for Ni/Si-Al $(7.7$, RT) catalyst it first increased and reached the maximum value at $240{ }^{\circ} \mathrm{C}$ and then decreased slowly when the reaction temperature was below $360^{\circ} \mathrm{C}$. There was a sharp decrease in the proportion of $\mathrm{C}_{10+}$ in liquid product at $360^{\circ} \mathrm{C}$, according to the above discussion, we can speculate that the reaction temperature is too high and cracking reaction occurred. 


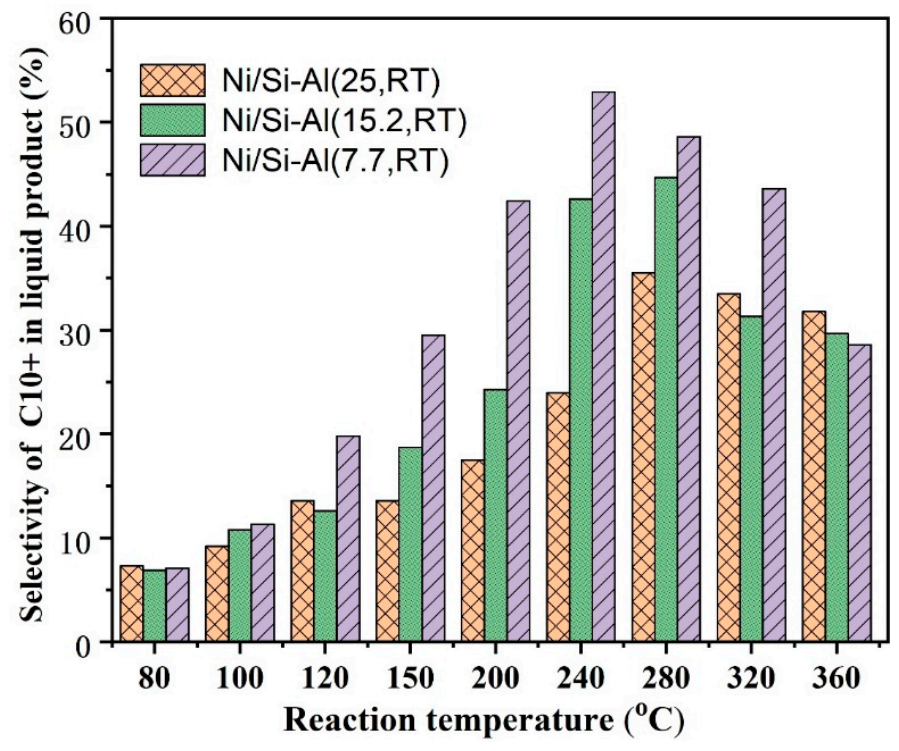

Figure 9. $\mathrm{C}_{10+}$ product of ethylene oligomerization catalyzed by Ni/Si-Al (25, RT), Ni/Si-Al (15.2, RT) and Ni/Si-Al (7.7, RT). Reaction conditions: Pressure: $3.5 \mathrm{MPa}$; WHSV: $2.0 \mathrm{~h}^{-1}$; Ni precursor: $\mathrm{Ni}\left(\mathrm{NO}_{3}\right)_{2}$; pretreatment temperature: $300^{\circ} \mathrm{C}$.

Moreover, the yield of $\mathrm{C}_{10+}$ products from Ni/Si-Al $(7.7, \mathrm{RT})$ was much higher than that from $\mathrm{Ni} / \mathrm{Si}-\mathrm{Al}(25, \mathrm{RT})$ and Ni/Si-Al$(15.2, \mathrm{RT})$ at the temperature range from 80 to $240{ }^{\circ} \mathrm{C}$. These results indicated that the lower $\mathrm{Si} / \mathrm{Al}$ ratio was in favor of obtaining high selectivity for $\mathrm{C}_{10+}$ products at a lower reaction temperature. Combining the characterization results of the catalysts, it can be found that the physical properties of samples exhibit a good relationship with the content of the $\mathrm{C}_{10+}$ olefins. We conclude that the specific surface area directly influences the dispersion of $\mathrm{Ni}$ species locating on the silica-alumina surface. As described earlier, because of the decrease in the $\mathrm{Si} / \mathrm{Al}$ ratio, the number of $\mathrm{Na}^{+}$ions increase during the preparation of silica-alumina. Since $\mathrm{Na}^{+}$ions are exchanged with $\mathrm{Ni}^{2+}$ ions, the loading content of $\mathrm{Ni}$ species is proportional to the content of $\mathrm{Na}^{+}$ions. As a result, more Ni species must disperse on the silica-alumina with lower surface area, which means the density of $\mathrm{Ni}$ species on the surface of support increased as the $\mathrm{Si} / \mathrm{Al}$ ratio decreased. Thus, it was thought high-density surface nickel could promote the conversion of ethylene into $\mathrm{C}_{10+}$ olefins.

When compared with Ni/Si-Al (25, RT) and Ni/Si-Al (15.2, RT), Ni/Si-Al (7.7, RT) had lower acid amounts but higher Ni loading content (Table 1), indicating higher Ni loading content played a more critical role than the acid amount in obtaining higher selectivity for $\mathrm{C}_{10+}$ products and lowering the reaction temperature.

\subsubsection{The Effect of Activation Temperature}

The catalyst $\mathrm{Ni} / \mathrm{Si}-\mathrm{Al}(7.7, \mathrm{RT})$ was chosen to investigate the effect of activation temperature because of its high catalytic performance based on the above results. Figure 10 showed the UV-vis spectrum of Ni/Si-Al $(7.7, \mathrm{RT})$ samples activated at different temperatures (no activation, $200^{\circ} \mathrm{C}, 400^{\circ} \mathrm{C}$ ). The peak at $270 \mathrm{~nm}$ was attributed to the three-coordinate $\mathrm{Ni}^{2+}\left(\mathrm{Ni}_{3 \mathrm{c}}{ }^{2+}\right)$, which was also observed by Klier [39] and Cornet [40]. This $270 \mathrm{~nm}$ peak was also related to the charge between $\mathrm{O}^{2-}(2 \mathrm{p})$ and $\mathrm{Ni}^{2+}(3 \mathrm{~d})$, which was different from the agglomerated $\mathrm{NiO}$ [41], indicating the well-dispersion of $\mathrm{NiO}$ on the support without agglomeration. This was in accordance with the XRD results where no NiO peaks were observed. There was no peak shift in $270 \mathrm{~nm}$, indicating that the status of $\mathrm{Ni}_{3 c}{ }^{2+}$ had nothing to do with the activation temperature. 


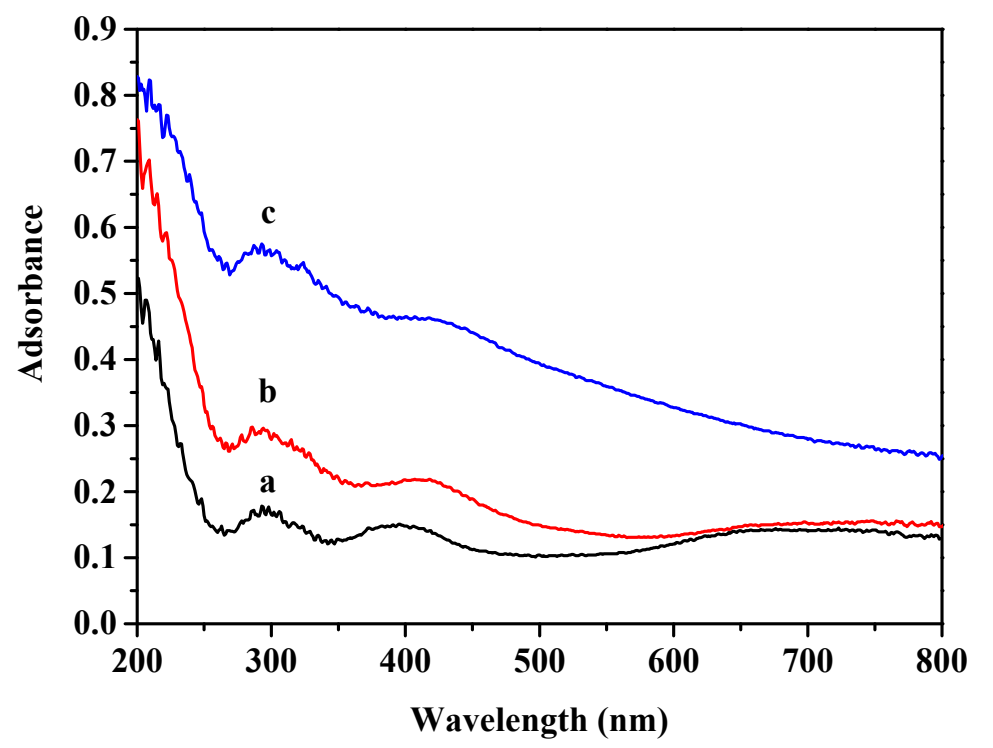

Figure 10. UV-Vis spectrum of $\mathrm{Ni} / \mathrm{Si}-\mathrm{Al}(7.7, \mathrm{RT})$ activated at (a) room temperature, $(\mathbf{b}) 20{ }^{\circ} \mathrm{C}$ and (c) $400{ }^{\circ} \mathrm{C}$, respectively.

However, the shoulder peak at $414 \mathrm{~nm}$ attributed to octahedral coordination $\mathrm{Ni}^{2+}[24,42-44]$ moved to a long wavelength gradually with an increased activation temperature. The intensity of this peak also decreased with increasing activation temperature. These results implied that the high activation temperature could affect the octahedral coordination $\mathrm{Ni}^{2+}$ in the way of reducing its amount, which was consistent with previous reports where the increased activation temperature could make octahedral coordination $\mathrm{Ni}^{2+}$ diffuse into support to form tetrahedral coordination $\mathrm{Ni}^{2+}$ [25,45-47].

Figure 11 showed the catalytic performance of $\mathrm{Ni} / \mathrm{Si}-\mathrm{Al}(7.7, \mathrm{RT})$ catalysts activated at room temperature, 200 and $400^{\circ} \mathrm{C}$. With the reaction time, the $\mathrm{C}_{10+}$ yield profile showed a similar trend where it first increased and then decreased. Unexpectedly, when the catalysts activated at room temperature, a sharp decrease (form $24.4 \%$ to about $4 \%$ ) in the $\mathrm{C}_{10+}$ yield profile at high temperature (above $240^{\circ} \mathrm{C}$ ). Compared with the sample that activated at room temperature, the sample activated at 200 and $400{ }^{\circ} \mathrm{C}$ delivered more $\mathrm{C}_{10+}$ product at all the temperature range used except 80 and $100{ }^{\circ} \mathrm{C}$. These results implied that the activation process done at relatively high temperature improves the selectivity for $\mathrm{C}_{10+}$ products. When compared with the catalyst activated at $200{ }^{\circ} \mathrm{C}$, higher $\mathrm{C}_{10+}$ products were obtained in the catalyst activated at $400{ }^{\circ} \mathrm{C}$, the same conclusion emerges when compared with the previous data (as shown in Figure 9). This superior property in $\mathrm{C}_{10+}$ selectivity of the catalyst activated at $400{ }^{\circ} \mathrm{C}$ mainly resulted from the decreased octahedral coordination $\mathrm{Ni}^{2+}$ (Figure 10). At a high reaction temperature above $240{ }^{\circ} \mathrm{C}$, the catalyst activated at $400{ }^{\circ} \mathrm{C}$ was also superior to that activated at $200^{\circ} \mathrm{C}$ in obtaining $\mathrm{C}_{10+}$ products. High $\mathrm{C}_{10+}$ products at high temperature indicated that the undesirable less side reactions occurred. Such a finding implied that more tetrahedral coordination $\mathrm{Ni}^{2+}$ was helpful to suppress the side reactions when reaction proceeded at high temperature because the catalyst activated at $400{ }^{\circ} \mathrm{C}$ had more content of tetrahedral coordination $\mathrm{Ni}^{2+}$ than that activated at $200{ }^{\circ} \mathrm{C}$. 


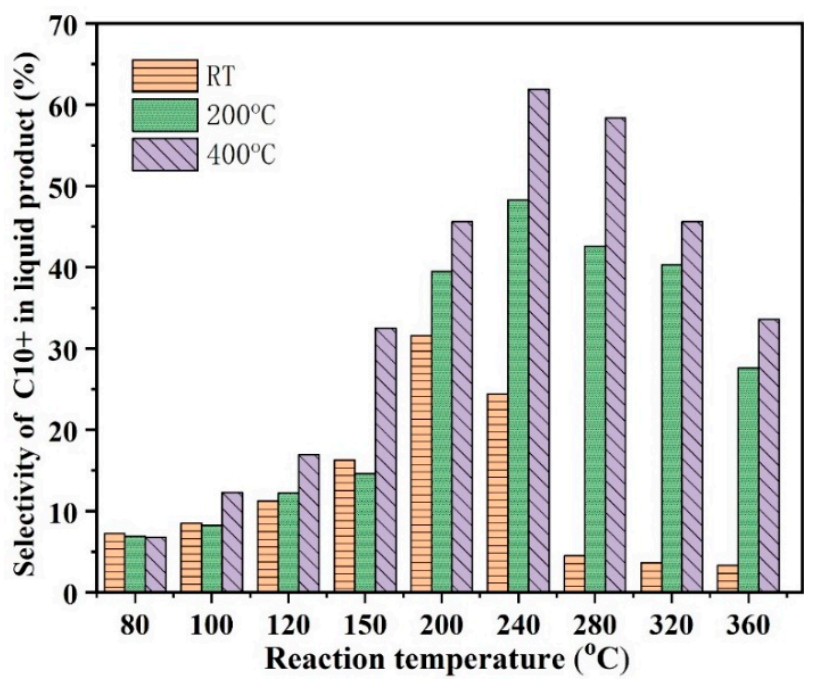

Figure 11. $\mathrm{C}_{10+}$ product of ethylene oligomerization catalyzed by Ni/Si-Al $(7.7, \mathrm{RT})$ activated at 200 and $400{ }^{\circ} \mathrm{C}$, respectively. Reaction conditions: pressure: $3.5 \mathrm{MPa}$; WHSV: $2.0 \mathrm{~h}^{-1}$; Ni precursor: $\mathrm{Ni}\left(\mathrm{NO}_{3}\right)_{2}$; aging temperature: room temperature.

\section{Materials and Methods}

\subsection{Preparation of Silica-Alumina Supports}

The type of silica-alumina support was prepared by the sol-gel method according to a previous report [34] with certain modification. Typically, a certain amount of $\mathrm{NaAlO}_{2}$ was firstly dissolved into $0.26 \mathrm{M} \mathrm{NaOH}$ solution as the solution A. Then, $39.8 \mathrm{~mL}$ of sodium silicate solution was diluted by $217 \mathrm{~mL}$ of water as the solution B. After that, $45.6 \mathrm{~mL}$ of solution A was added into the solution $\mathrm{B}$, then $86 \mathrm{~mL}$ of $1.4 \mathrm{M}$ nitric acid was added into above mixture with stirring for $0.5 \mathrm{~h}$. Finally, $\mathrm{pH}$ was adjusted to 9 using $\mathrm{NaOH}$ solution. The mixture was further aged at room temperature or $80^{\circ} \mathrm{C}$ without stirring for 3 days, and then precipitation was filtered, washed with deionized water until the wash water was neutral and dried at $80^{\circ} \mathrm{C}$ overnight and calcined at $550{ }^{\circ} \mathrm{C}$ for $3 \mathrm{~h}$. The $\mathrm{Na}^{+}$-form of the solid silica-alumina thus was synthesized.

\subsection{Preparation of Nickel Supported Silica-Alumina by Ion-Exchange Method}

$\mathrm{Ni}$ loading catalyst was prepared by ion-exchanging the obtained silica-alumina powder with an aqueous solution of nickel metal salts at $60^{\circ} \mathrm{C}$ with stirring for $6 \mathrm{~h}$. The molar concentration of the nickel solution was $8 \mathrm{~mol} / \mathrm{L}$ and using three moles of nickel (II) for every two moles of aluminum in the silica-alumina support. After that, the green solid was filtered, washed with deionized water for several times and dried at $110^{\circ} \mathrm{C}$ for $6 \mathrm{~h}$, and then nickel supported silica-alumina catalysts were obtained. The synthesized catalysts were labeled as $\mathrm{Ni} / \mathrm{Si}-\mathrm{Al}(\mathrm{x}, \mathrm{y})$, where $\mathrm{x}$ represents the $\mathrm{Si} / \mathrm{Al}$ ratio and $\mathrm{y}$ is the aging temperature in which RT means room temperature.

\subsection{Characterizations}

X-ray diffraction (XRD) measurements were carried out on a Bruker AXS-D8 Advance powder diffractometer using $\mathrm{Cu} \mathrm{K} \alpha$ radiation $(40 \mathrm{kV}, 40 \mathrm{~mA})$, with a step size of $0.02^{\circ}(2 \theta)$ and 2 s per step over the $2 \theta$ range from $10^{\circ}$ to $70^{\circ}$. The nitrogen adsorption-desorption isotherms at $77 \mathrm{~K}$ were determined on an Autosorb-6B instrument, using nitrogen of $99.999 \%$ purity. Transmission electron microscopy (TEM) studies were carried out on a Hitachi H-7650 electron microscope with an accelerating voltage of $100 \mathrm{kV}$. Temperature-programmed desorption of ammonia ( $\mathrm{NH}_{3}-\mathrm{TPD}$ ) for acidity analysis was carried out in a Micromeritics 2920TR Chemisorption Analyzer. One hundred and fifty $\mathrm{mg}$ of sample was pretreated at $873 \mathrm{~K}$ in Ar flow for $2 \mathrm{~h}$. After cooled down to room temperature, a pure $\mathrm{NH}_{3}$ was adsorbed for $2 \mathrm{~h}$. Desorption of $\mathrm{NH}_{3}$ was monitored in the temperature range of $373-773 \mathrm{~K}$ with the heating 
rate of $10 \mathrm{~K} / \mathrm{min}$. Uv-vis absorption characterization was tested using Hitachi $\mathrm{u}-4100$, the scanning wavelength range is $200-900 \mathrm{~nm}$ and the scanning rate is $300 \mathrm{~nm} / \mathrm{min}$. XRF was used to determine the amount of element in the catalysts using Panalytical Axios PW 4400-X-ray fluorescence spectroscopy.

\subsection{Catalytic Experiment}

The catalytic experiment was performed in a fixed-bed micro-reactor. Prior to each experiment, the catalysts were firstly activated at $300{ }^{\circ} \mathrm{C}$ and $50 \mathrm{~mL} / \mathrm{min}$ He before introducing ethylene. The reactor was then heated to a certain temperature with introducing ethylene (3.5 MPa and $2 \mathrm{~h}^{-1}$ of WHSV). Prior to the reaction, the ethylene was absorbed by the mixture of $\mathrm{NaOH}, 4 \mathrm{~A}$ zeolite and anhydrous $\mathrm{CaCl}_{2}$ for purification. The reaction system is shown in Figure S1.

The gas products were analyzed with on-line gas chromatographs (Agilent 7890A) equipped with HP-PLOT/Q capillary column $(30 \mathrm{~m} \times 0.32 \mathrm{~mm} \times 20 \mu \mathrm{m})$ and FID (flamed ionized detector), while liquid products were analyzed with HP-INNOWAX capillary column $(30 \mathrm{~m} \times 0.25 \mathrm{~mm} \times 0.25 \mu \mathrm{m})$. The compositions of products were identified using Agilent 5975 inert XL MSD GC/MS instrument. The conversion of ethylene and its selectivity to olefins were calculated by the area of FID signal of each compound.

\section{Conclusion}

Three kinds of amorphous silica-alumina with different $\mathrm{Si} / \mathrm{Al}$ ratios and the corresponding $\mathrm{Ni} / \mathrm{Si}-\mathrm{Al}$ catalysts were prepared by the ion-exchange method. Under all the experimental conditions employed in this study, the conversions of ethylene were over $95 \%$. The aging temperature, $\mathrm{Si} / \mathrm{Al}$ ratio and activation temperature affected the catalytic performance of $\mathrm{Ni}$ loading silica-alumina catalysts through making changes in the acid sites, Ni loading amount, surface area and the type of Ni species rather than the amorphous structure. High $\mathrm{Ni}$ loading content was more important for higher $\mathrm{C}_{10+}$ production than the surface area and acid mount while increased tetrahedral coordination $\mathrm{Ni}^{2+}$ tend to suppress the side reactions when catalysts were used at high temperature. The better catalytic performance for obtaining more $\mathrm{C}_{10+}$ products can be achieved in catalysts with low $\mathrm{Si} / \mathrm{Al}$ ratio, high aging and activation temperature. In addition, the effects of several reaction conditions on the ethylene oligomerization activity of $\mathrm{Ni} / \mathrm{Si}-\mathrm{Al}$ were investigated. It is found that increasing reaction temperature, aging temperature, and pretreatment temperature are favorable for the formation of $\mathrm{C}_{10+}$ olefins.

Supplementary Materials: Supplementary materials are available online at http://www.mdpi.com/2073-4344/ 10/2/180/s1. Table S1: Textural properties of Ni/Si-Al(x,y) determined by $\mathrm{N}_{2}$ adsorption-desorption, Table S2. The acid distribution of $\mathrm{Ni} / \mathrm{Si}-\mathrm{Al}(\mathrm{x}, \mathrm{y})$ from $\mathrm{NH}_{3}-\mathrm{TPD}$, Figure $\mathrm{S} 1 . \mathrm{NH}_{3}-\mathrm{TPD}$ profiles of Ni/Si-Al $(\mathrm{x}, \mathrm{y})$, Figure S2. Schematic diagram of ethylene oligomerization unit.

Author Contributions: Conceptualization, L.C., G.L. and X.L.; Data curation, L.C.; Formal analysis, L.C.; Funding acquisition, X.L.; Investigation, L.C.; Resources, G.L., Z.W., M.Z. and S.L.; Software, S.L.; Supervision, X.L.; Visualization, L.C.; Writing-original draft, L.C.; Writing-review \& editing, L.C. All authors have read and agree to the published version of the manuscript.

Funding: Financial supports from the National Natural Science Foundation of China (No. 21676287, 21761132006) are gratefully acknowledged.

Conflicts of Interest: The authors declare no conflict of interest.

\section{References}

1. Bond, J.Q.; Alonso, D.M.; Wang, D.; West, R.M.; Dumesic, J.A. Integrated Catalytic Conversion of Gamma-Valerolactone to Liquid Alkenes for Transportation Fuels. Science 2010, 327, 1110-1114. [CrossRef] [PubMed]

2. Shahinuzzaman, M.; Yaakob, Z.; Ahmed, Y. Non-sulphide zeolite catalyst for bio-jet-fuel conversion. Renew. Sustain. Energy Rev. 2017, 77, 1375-1384. [CrossRef]

3. Jan, O.; Song, K.; Dichiara, A.; Resende, F.L.P. Ethylene Oligomerization over Ni-H beta Heterogeneous Catalysts. Ind. Eng. Chem. Res. 2018, 57, 10241-10250. [CrossRef] 
4. Stöcker, M. Methanol-to-hydrocarbons: Catalytic materials and their behavior. Microporous Mesoporous Mater. 1999, 29, 3-48. [CrossRef]

5. Haw, J.F.; Song, W.G.; Marcus, D.M.; Nicholas, J.B. The Mechanism of Methanol to Hydrocarbon Catalysis. Acc. Chem. Res. 2003, 36, 317-326. [CrossRef]

6. Finiels, A.; Fajula, F.; Hulea, V. Nickel-based solid catalysts for ethylene oligomerization-A review. Catal. Sci. Technol. 2014, 4, 2412-2426. [CrossRef]

7. Al-Jarallah, A.; Anabtawi, J.; Siddiqui, M.; Aitani, A.; Al-Sa'Doun, A. Ethylene dimerization and oligomerization to butene- 1 and linear $\alpha$-olefins. Catal. Today 1992, 14, 1-121. [CrossRef]

8. Sarkar, A.; Seth, D.; Ng, F.T.T.; Rempel, G.L. Selective Oligomerization of lsobutene on Lewis Acid Catalyst: Kinetic Modeling. Ind. Eng. Chem. Res. 2014, 53, 18982-18992. [CrossRef]

9. Hartmann, M.; Kevan, L. Transition-metal ions in aluminophosphate and silicoaluminophosphate molecular sieves: Location, interaction with adsorbates and catalytic properties. Chem. Rev. 1999, 99, 635-664. [CrossRef]

10. Fliedel, C.; Ghisolfi, A.; Braunstein, P. ChemInform Abstract: Functional Short-Bite Ligands: Synthesis, Coordination Chemistry, and Applications of N-Functionalized Bis(diaryl/Dialkylphosphino)amine-type Ligands. Chem. Rev. 2016, 47, 9237-9304. [CrossRef]

11. McGuinness, D.S. Olefin Oligomerization via Metallacycles: Dimerization, Trimerization, Tetramerization, and Beyond. Chem. Rev. 2011, 111, 2321-2341. [CrossRef]

12. Van Leeuwen, P.W.; Clément, N.D.; Tschan, M.J.-L. New processes for the selective production of 1-octene. Co-Ord. Chem. Rev. 2011, 255, 1499-1517. [CrossRef]

13. Ittel, S.D.; Johnson, L.K.; Brookhart, M. Late-Metal Catalysts for Ethylene Homo- and Copolymerization. Chem. Rev. 2000, 100, 1169-1204. [CrossRef]

14. Hengsawad, T.; Srimingkwanchai, C.; Butnark, S.; Resasco, D.E.; Jongpatiwut, S. Effect of Metal-Acid Balance on Hydroprocessed Renewable Jet Fuel Synthesis from Hydrocracking and Hydroisomerization of Biohydrogenated Diesel over Pt-Supported Catalysts. Ind. Eng. Chem. Res. 2018, 57, 1429-1440. [CrossRef]

15. Wang, W.-C.; Tao, L. Bio-jet fuel conversion technologies. Renew. Sustain. Energy Rev. 2016, 53, 801-822. [CrossRef]

16. Liu, G.; Yan, B.; Chen, G. Technical review on jet fuel production. Renew. Sustain. Energy Rev. 2013, 25, 59-70. [CrossRef]

17. Britovsek, G.J.P.; Malinowski, R.; McGuinness, D.S.; Nobbs, J.D.; Tomov, A.K.; Wadsley, A.W.; Young, C.T. Ethylene Oligomerization beyond Schulz-Flory Distributions. ACS Catal. 2015, 5, 6922-6925. [CrossRef]

18. Keim, W. Oligomerization of Ethylene to alpha-Olefins: Discovery and Development of the Shell Higher Olefin Process (SHOP). Angew. Chem.-Int. Ed. 2013, 52, 12492-12496. [CrossRef]

19. Breuil, P.-A.R.; Magna, L.; Olivier-Bourbigou, H. Role of Homogeneous Catalysis in Oligomerization of Olefins: Focus on Selected Examples Based on Group 4 to Group 10 Transition Metal Complexes. Catal. Lett. 2014, 145, 173-192. [CrossRef]

20. Dagorne, S.; Fliedel, C. Organoaluminum Species in Homogeneous Polymerization Catalysis. Photophys. Organomet. 2012, 41, 125-171.

21. Zhang, Q.; Kantcheva, M.; Lana, I.G.D. Oligomerization of Ethylene in a Slurry Reactor Using a Nickel/Sulfated Alumina Catalyst. Ind. Eng. Chem. Res. 1997, 36, 3433-3438. [CrossRef]

22. Lin, S.; Shi, L.; Zhang, H.; Zhang, N.; Yi, X.; Zheng, A.; Li, X. Tuning the pore structure of plug-containing Al-SBA-15 by post-treatment and its selectivity for C16 olefin in ethylene oligomerization. Microporous Mesoporous Mater. 2014, 184, 151-161. [CrossRef]

23. Andrei, R.D.; Popa, M.I.; Fajula, F.; Hulea, V. Heterogeneous oligomerization of ethylene over highly active and stable Ni-AlSBA-15 mesoporous catalysts. J. Catal. 2015, 323, 76-84. [CrossRef]

24. Heydenrych, M.D.; Nicolaides, C.P.; Scurrell, M.S. Oligomerization of Ethene in A Slurry Reactor using A Nickel(II)-exchanged Silica-alumina. Catal. J. Catal. 2001, 197, 49-57. [CrossRef]

25. Hulea, V. Ni-exchanged AlMCM-41? An efficient bifunctional catalyst for ethylene oligomerization. J. Catal. 2004, 225, 213-222. [CrossRef]

26. Tanaka, M.; Itadani, A.; Kuroda, Y.; Iwamoto, M. Effect of Pore Size and Nickel Content of Ni-MCM-41 on Catalytic Activity for Ethene Dimerization and Local Structures of Nickel Ions. J. Phys. Chem. C 2012, 116, 5664-5672. [CrossRef] 
27. Lallemand, M.; Finiels, A.; Fajula, F.; Hulea, V. Catalytic oligomerization of ethylene over Ni-containing dealuminated Y zeolites. Appl. Catal. A Gen. 2006, 301, 196-201. [CrossRef]

28. Lallemand, M.; Rusu, O.A.; Dumitriu, E.; Finiels, A.; Fajula, F.; Hulea, V. NiMCM-36 and NiMCM-22 catalysts for the ethylene oligomerization: Effect of zeolite texture and nickel cations/acid sites ratio. Appl. Catal. A Gen. 2008, 338, 37-43. [CrossRef]

29. Heveling, J.; Van Der Beek, A.; De Pender, M. Oligomerization of ethene over nickel-exchanged zeolite y into a diesel-range product. Appl. Catal. 1988, 42, 325-336. [CrossRef]

30. Wang, X.; Hu, X.; Song, C.; Lux, K.W.; Namazian, M.; Imam, T. Oligomerization of Biomass-Derived Light Olefins to Liquid Fuel: Effect of Alkali Treatment on the HZSM-5 Catalyst. Ind. Eng. Chem. Res. 2017, 56, 12046-12055. [CrossRef]

31. Avhad, M.; Marchetti, J.M. A review on recent advancement in catalytic materials for biodiesel production. Renew. Sustain. Energy Rev. 2015, 50, 696-718. [CrossRef]

32. Martinez, A.; Arribas, M.A.; Concepcion, P.; Moussa, S. New bifunctional Ni-H-Beta catalysts for the heterogeneous oligomerization of ethylene. Appl. Catal. A Gen. 2013, 467, 509-518. [CrossRef]

33. Ng, F.; Creaser, D. Ethylene dimerization over modified nickel exchanged Y-zeolite. Appl. Catal. A Gen. 1994, 119, 327-339. [CrossRef]

34. Heveling, J.; Nicolaides, C.; Scurrell, M. Catalysts and conditions for the highly efficient, selective and stable heterogeneous oligomerisation of ethylene. Appl. Catal. A Gen. 1998, 173, 1-9. [CrossRef]

35. Brunauer, S.; Deming, L.S.; Deming, W.E.; Teller, E. On a Theory of the van der Waals Adsorption of Gases. J. Am. Chem. Soc. 1940, 62, 1723-1732. [CrossRef]

36. Tanabe, K.; Sumiyoshi, T.; Shibata, K.; Kiyoura, T.; Kitagawa, J. A New Hypothesis Regarding the Surface Acidity of Binary Metal Oxides. Bull. Chem. Soc. Jpn. 1974, 47, 1064-1066. [CrossRef]

37. Grabowski, W. Quantum chemical study of acid-base properties of metal oxides. I. J. Catal. 1980, 61, $103-108$. [CrossRef]

38. Serrano, D.P.; Aguado, J.; Escola, J.M. Developing Advanced Catalysts for the Conversion of Polyolefinic Waste Plastics into Fuels and Chemicals. ACS Catal. 2012, 2, 1924-1941. [CrossRef]

39. Klier, K.; Ralek, M. Spectra of Zynthetic Zolites Containing Transition Metal Ions-II. Ni ${ }^{2+}$ Ions in Type A Linde Molecular Sieves. J. Phys. Chem. Solids 1968, 29, 951-957. [CrossRef]

40. Cornet, D.; Hemidy, J.F.; Mariette, L. Spectroscopic Classification of Interactions between Metallic Support Ions-Case of the Nio- $\mathrm{Al}_{2} \mathrm{O}_{3}$ System. Nouv. J. Chim. New J. Chem. 1984, 8, 159-164.

41. Garbarino, G.; Campodonico, S.; Perez, A.R.; Carnasciali, M.M.; Riani, P.; Finocchio, E.; Busca, G. Spectroscopic characterization of $\mathrm{Ni} / \mathrm{Al}_{2} \mathrm{O}_{3}$ catalytic materials for the steam reforming of renewables. Appl. Catal. A Gen. 2013, 452, 163-173. [CrossRef]

42. Nikolova, D.; Edreva-Kardjieva, R.; Glurginca, M.; Meghea, A.; Vakros, J.; Voyiatzis, G.A.; Kordulis, C. The Effect of Potassium Addition on the State of the Components in the Oxide Precursor of the (Ni)(Mo)/gamma- $\mathrm{Al}_{2} \mathrm{O}_{3}$ Water-gas Shift Catalysts: FT-TR, Diffuse Reflectance and Raman Spectroscopic Studies. Vib. Spectrosc. 2007, 44, 343-350. [CrossRef]

43. Zanjanchi, M.A.; Ebrahimian, A. Studies on the Solid-state on Exchange of Nickel Ions into Zeolites using DRS Technique. J. Mol. Struct. 2004, 693, 211-216. [CrossRef]

44. Yang, L.; Xia, K.H. D-orbital for $\mathrm{Ni}^{2+}$ in the Ni(II) Semisepulchrates. Solid State Commun. 1994, 90, 737-739. [CrossRef]

45. Čapek, L.; Vaněk, L.; Smoláková, L.; Bulánek, R.; Adam, J. The Feasibility of Ni-Alumina Catalysts in Oxidative Dehydrogenation of Ethane. Collect. Czechoslov. Chem. Commun. 2008, 73, 1177-1191. [CrossRef]

46. Chareonpanich, M.; Teabpinyok, N.; Kaewtaweesub, S. Effect of Nickel Particle Size on Dry Reforming Temperature. In Proceedings of the World Congress on Engineering and Computer Science; International Association of Engineers: Hong Kong, China, 2008; pp. 98-102.

47. Kim, J.-H.; Suh, D.J.; Park, T.-J.; Kim, K.-L. Effect of metal particle size on coking during $\mathrm{CO}_{2}$ reforming of CH4 over Ni-alumina aerogel catalysts. Appl. Catal. A Gen. 2000, 197, 191-200. [CrossRef]

(C) 2020 by the authors. Licensee MDPI, Basel, Switzerland. This article is an open access article distributed under the terms and conditions of the Creative Commons Attribution (CC BY) license (http://creativecommons.org/licenses/by/4.0/). 